\title{
CHANGES OF THE EEL FISHERY PATTERNS IN THE VISTULA LAGOON, POLAND
}

\author{
Iwona PSUTY* and Bohdan DRAGANIK
}

\author{
Sea Fisheries Institute in Gdynia, Poland
}

\begin{abstract}
Psuty I., Draganik B. 2008. Changes of the eel fishery patterns in the Vistula Lagoon, Poland. Acta Ichthyol. Piscat. 38 (2): 113-120.
\end{abstract}

\begin{abstract}
Background. The decline in the eel population is reflected in the decreased incomes of fishers. This has led to changes in the structure and size of the fishing effort. The fyke nets used in eel catches are multi-species gear. Changes in the fishing intensity and location of this gear impacts local fish resources, as does changing preferred gear for other types.

Materials and Methods. The data on the eel landings and the numbers of licences from all the fisheries bases were obtained from the Regional Sea Fisheries Inspectorate. Direct observations of the spatial and temporal deployment of the fishing effort was observed monthly in the 2000-2007 period. The trends of changes in relative eel abundance were identified from fyke net complexes deployed in the eastern fishing grounds.

Results. Landings and directed fishing effort differed both seasonally and spatially. The most effective fishing grounds were in the eastern (near the border with Russia) and western parts of the lagoon. The discontinuation of stocking resulted in decreased catches and then in fishing effort. Decreases in eel catches and fishing efficiency were evident except in 2003 at the Piaski and Kąty Rybackie fisheries bases (the northern part of the lagoon). Conclusions. The availability of eel stocks had the greatest impact on fishing efficiency and gear distribution patterns. The reduction of fyke net fishery because of low incomes shifted the focus of the fishery to gill nets targeting pikeperch.
\end{abstract}

Keywords: Fyke net, Anguilla anguilla, Poland, small-scale fishery, fishing effort

\section{INTRODUCTION}

The European eel Anguilla anguilla (L.) has been exploited in the majority of European waters. More than 25000 people earn substantial income from eel fisheries (Moriarty and Dekker 1997). In Poland before 1989, live eel were of particular interest to the management of the centrally planned economy as an export product sold in the West. Eel has traditionally been a luxury product in Poland that has been used as alternative currency for the expression of gratitude for poorly accessible goods or services. Until recently, smoked eel was nearly always a featured dish at Polish wedding receptions and other celebrations. This steady demand ensured that fishers who exploited eel resources earned adequate profits. In the 2000-2007 period the price per $\mathrm{kg}$ of eel was an average of threefold higher than that of pike-perch, Sander lucioperca (L.), and twentyfold higher than that of large (over $1.5 \mathrm{~kg}$ ) common bream, Abramis brama (L.). The remaining fish species caught by small-scale multi-species fishery such as European perch, Perca fluviatilis L., roach, Rutilus rutilus (L.), and ziege, Pelecus cultratus (L.), have never played a significant role in the profits earned by Vistula Lagoon fishers.
Vistula Lagoon fisheries did not feel the impact of the European-wide decline in eel stocks for a relatively long time (Moriarty 1996). Thanks to the stocking carried out in the 1970s, the catches were the highest in the 1980s and 1990s (Psuty and Draganik 2008). Since fishing in the lagoon is spatially limited, the eel fishing effort targeted the maximum exploitation of the best fishing grounds and the most profitable fishing periods. The location of fyke nets was the root cause of many conflicts among Vistula Lagoon fishers.

In the early 21 st century, the discontinuation of stocking was reflected in the increasingly rare occurrence of eel, and in quantities that were incomparable to the previous period. This spurred a shift in fyke net fishing effort that was dictated by economic considerations.

The aim of this work is to evaluate changes in the fishing effort and fishing efficiency in fyke net fisheries in the Vistula Lagoon in the 2000-2007 period.

\section{MATERIAL AND METHODS}

Study area. The Vistula Lagoon is a brackish water basin on the southern coast of the Baltic Sea. Its surface area is $838 \mathrm{~km}^{2}$, and $39 \%$ of this area is located within

\footnotetext{
* Correspondence: Dr Iwona Psuty, Morski Instytut Rybacki w Gdyni, Kołłątaja 1, 81-332 Gdynia, Poland, phone: +48 587356218 , fax: +48 58 7356 110, e-mail: iwcia@mir.gdynia.pl
} 
Polish borders. The physical conditions of the basin that support fish assemblage habitats are variable, including salinity (ranging from 0.1 PSU in the south-western part to 4.5 PSU near the Polish-Russian border), the intensity of water and bottom sediment mixing, and the content of organic matter in the water (Lazarienko and Majewski 1975). According to the Polish water typology of the Water Framework Directive, this lagoon is transitional, sheltered from the sea, and has oligohaline waters (Krzymiński et al. 2004). The shallow depth, developed shorelines, and high productivity of this lagoon have supported the development of small-scale fisheries fleets. The fisheries of this lagoon targets eel (fyke net fishery) and pike-perch (gill net fishery), but multiple species are caught by both. them (e.g., insurance, the purchase of gear under preferential conditions, guaranteed fish sales). Following the economic and political transformations of the 1990s, the small-scale fishery sector was fully privatized. Poland entered a period of rapid transformation that included cultural changes in communities (Sztompka 1996) that had previously taken advantage of wide-ranging state assistance. In the case of small-scale fisheries in lagoons, this affected the glass eel stocking program, which was discontinued in the 1990s and resulted in a drastic reduction in catches of this species ten years later. Many fishers shifted targeted catches from eel to pike-perch, which resulted in overfishing of the latter species. The EU-sponsored fleet reduction program in the 2004-2006 period made it easier for fishers to give up fishing.

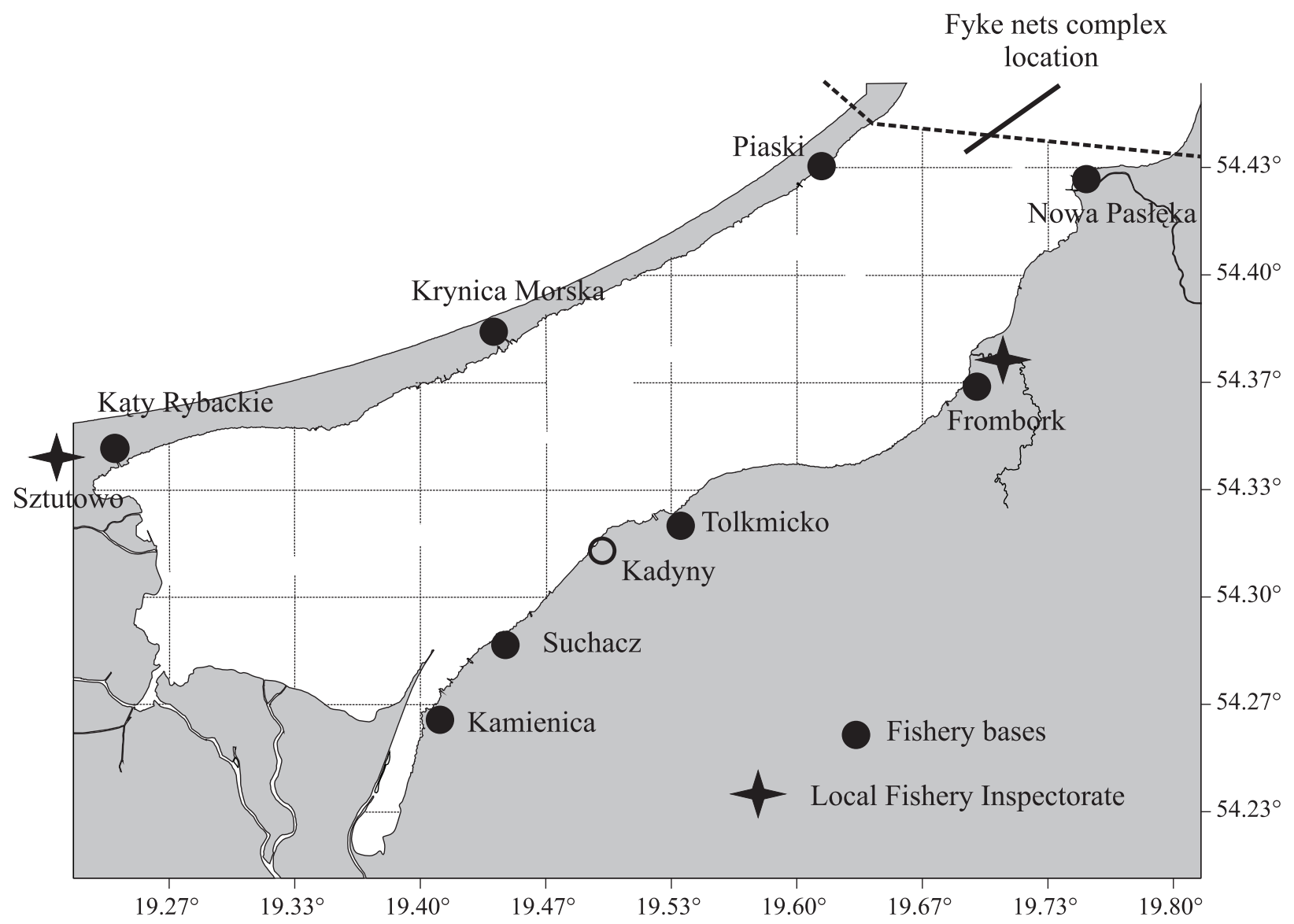

Fig. 1. Map of the studied area with network of squares used to monitor the fishing effort

Fisher community. The Vistula Lagoon was under exclusive German administration until 1945, but following World War II the local populations were relocated, and the fisheries were taken over by new inhabitants that had come mainly from the south of Poland. The prevailing ownership structure of the fishing gear and the vessels as well as the organization of the fisheries all changed. Until 1989 (when the political system in Poland began to change), the lagoon fisheries were largely organized as fishing cooperatives, which differed from agriculture cooperatives, at that time. The fishers employed by the cooperatives had many rights, and they took advantage of
Catch statistics. In the 2000-2004 period, catch statistics were gathered by the Regional Maritime Fishery Inspectorates in Frombork and Sztutowo. Catch records were filed by fishers at monthly intervals. The data were recorded into the regional database in Regional Maritime Fishery Inspectorate in Gdynia. From 2005, the catch data were sent to the Centre of Fishery Monitoring in Warsaw. Due to the requirements of on-going monitoring of pikeperch and bream quotas, the former regional database is still maintained.

Distribution of effort. The number and the distribution of fyke nets in the Vistula Lagoon was registered by 
inspectors from the Regional Marine Fisheries Inspectorates in Frombork (southern lagoon) and Sztutowo (northern lagoon) based on observations during surveys. The day of record was designated as every third week of each month, and both sides of the lagoon were observed simultaneously within one to three days. The number of gears deployed within a network of squares was noted on a map (Fig. 1). This number was designated as the mean for a whole month.

Catch efficiency. Indicators of catch efficiency over a series of years were determined based on catches registered by fishers performing self-sampling of fyke net complexes located near the Polish-Russian border. These gears are deployed by individual fishing crews that have obtained a special fishing licence to work in the protected border area where there is mass fish migration; the aim of this is to eliminate the impact of other fishing gears. The characteristics of the fyke net complexes and the methodology for registering data is presented in the work by Wilkońska and Psuty (2008). The months of May and September were chosen to evaluate the trends in changes of eel catch efficiency.
The highest catches were noted at the beginning of this period by the fishers from the bases near the borderNowa Pasłęka and Piaski. The fishing bases situated in the middle section of the lagoon reported catches that were half as large (Tolkmicko and Frombork). Fishing bases located in the southwestern part of the lagoon (Suchacz and Kamienica) did not play a significant role in the eel fisheries during the analyzed time period, similarly to Krynica Morska. In 2003, however, catches registered in Kąty Rybackie and Nowa Pasłęka exceeded previous results for these two bases.

The decrease in catch size was followed by a decline in the numbers of licensed boats operating in the Vistula Lagoon (Table 1). The maximum numbers of fyke nets per licence was 30 in 2005, but this potential effort was never executed in practice. The estimated effort decreased more than fourfold, but the estimated effort per licence decreased only 2.5 -fold.

The seasonality of the catches during the analyzed period was variable. Within 2000-2002, the highest results were recorded in September (Table 2). In 2003, the most eels were caught in September and October. In sub-

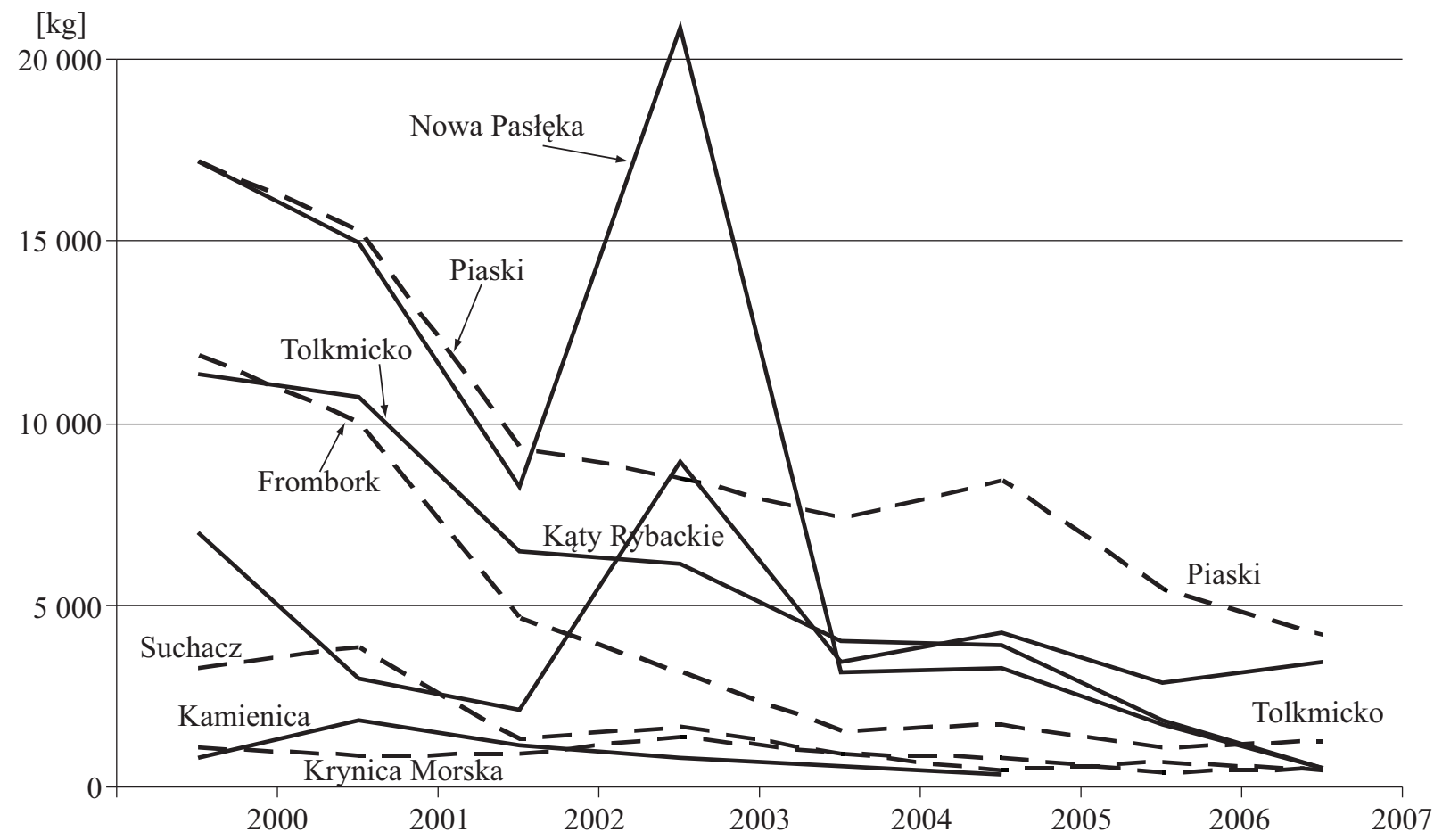

Fig. 2. Eel landings from the Vistula Lagoon fishery bases in the 2000-2007 period

Indicators of fisheries efficiency were determined based on results registered by fishers from three fishing bases located in various parts of the lagoon-Kąty Rybackie, Tolkmicko, and Piaski. The total registered eel catches were divided by the number of fishing licences granted for a given base in a given year.

\section{RESULTS}

Catch and effort data. Landings declined at all of the fishing bases over the eight years of the study (Fig. 2). sequent years, the role of the fall months declined, and eel catches became fairly evenly distributed throughout the year, with the highest relative catches noted in May.

Effort distribution. The registered effort was not evenly distributed throughout the fishing area. There are two fishing grounds in the Polish part of the Vistula Lagoon, which is where most of the fyke nets were deployed, and both were located on the edges of the lagoon. The eastern fishing area, near the border, was exploited more during the initial part of the analyzed peri- 
Table 1

Landings and fyke net effort deployed at the Polish part of the Vistula Lagoon in 2000-2007 period

\begin{tabular}{ccccc}
\hline Year & $\begin{array}{c}\text { Landings } \\
{[\mathrm{kg}]}\end{array}$ & $\begin{array}{c}\text { Licence } \\
\text { numbers }\end{array}$ & $\begin{array}{c}\text { Effort } \\
\text { [fyke net/days] }\end{array}$ & $\begin{array}{c}\text { Effort per licence } \\
\text { [fyke net/days] }\end{array}$ \\
\hline 2000 & 69738 & 122 & 328740 & 2695 \\
2001 & 60512 & 123 & 290880 & 2365 \\
2002 & 34182 & 122 & 233160 & 1911 \\
2003 & 51414 & 120 & 157230 & 1310 \\
2004 & 21937 & 119 & 144150 & 1211 \\
2005 & 23070 & 95 & 125250 & 1318 \\
2006 & 14055 & 66 & 81360 & 1233 \\
2007 & 10936 & 65 & 70650 & 1087 \\
\hline
\end{tabular}

Table 2

Monthly percentage of eel landings in different periods

\begin{tabular}{lccc}
\hline Month & $\begin{array}{c}2000-2002 \\
\text { (mean) }\end{array}$ & 2003 & $\begin{array}{c}\text { 2005-2007 } \\
\text { (mean) }\end{array}$ \\
\hline March & 0.2 & 0.0 & 0.1 \\
April & 2.5 & 2.1 & 5.4 \\
May & 15.1 & 14.0 & 22.8 \\
June & 6.3 & 17.3 & 17.8 \\
July & 5.4 & 6.0 & 12.5 \\
August & 12.9 & 7.5 & 12.0 \\
September & 41.3 & 23.4 & 17.9 \\
October & 15.2 & 29.0 & 9.2 \\
November & 1.0 & 0.6 & 2.1 \\
December & 0.1 & 0.1 & 0.1 \\
\hline
\end{tabular}

od (Fig. 3). The western fishing ground, which includes the rivers and canals of the Vistula River delta, have become more significant to fyke net fisheries in recent years. The greater number of fyke net months registered throughout the year noted in the western fishing ground was linked to the longer fyke net deployment season, which included exploitation in the summer months of June and July.

In 2000 the most of the fishing effort was registered from August to October (Fig. 4). A similar seasonal trend was maintained throughout the period in which the distribution of the fishing effort was recorded.

The distribution of the fishing effort according to which base it originated from was dependent on distance, with the exception of the near-border fishing grounds. Legislation regulating the positions taken by fishermen in these fishing grounds has been a source of conflict since as early as the beginning of the 1980s. By the end of the decade, many fishermen competed to claim the best fyke net deployment location. This prompted them to invest in unsafe, high-powered boat engines. Currently, the positions held at the fishing grounds are those that were determined by the results of the last spring race held in 1995 . The most fishing sites in the best locations were claimed by the fishers from bases in Nowa Pasłęka and Piaski, which are located closest to the border. Positions designated on the first two lines of gear deployment from the border are, however, divided as follows: one crew can have only one place in a given line. Thanks to this regulation, crews from most of the fishing bases, except those located the farthest away in Kąty Rybackie, Kamienica, and Suchacz, deploy their gear in the near-border fishing ground especially during fall.

\section{Fishing efficiency}

Relative eel fishing efficiency in fyke net complexes in the border region declined in September fourteenfold (Fig. 5). An even greater decline in efficiency was registered in May. The fishing efficiency calculated as the number of catches per licence also decreased (Table 3 ). The greatest decline, which was in excess of sixfold, was recorded at the Tolkmicko fishing base located in the middle section of the lagoon. Efficiency decreased over twofold at Kąty Rybackie, while that registered at Piaski in 2000 and 2007 did not differ significantly, and the highest values were noted in 2003 .

\section{DISCUSSION}

Deployment of fyke net complexes requires much preparation prior to the fishing season and substantial physical strength during deployment. The high organic matter content in the water of the Vistula Lagoon and the prohibition of the environmentally dangerous anti-fouling agent TBTO, which was in widespread use in the 1980s, 


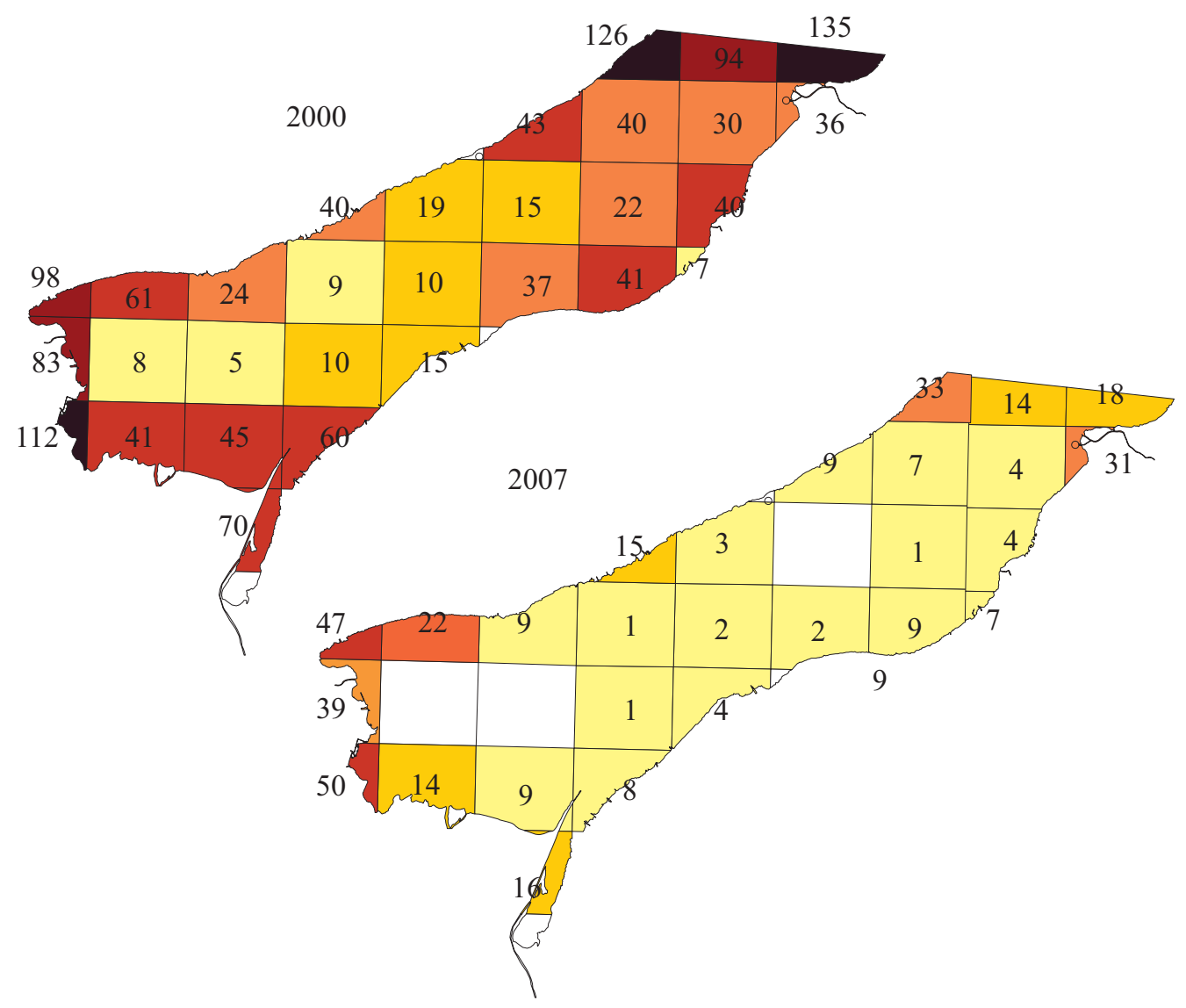

No fishing Number of fyke nets months per square kilometer in 2000 and 2007 with fyke-net

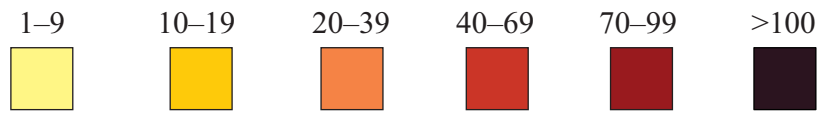

Fig. 3. Distribution of fyke nets in the lagoon in the 2000-2007 period

means that any gear left in the water becomes overgrown with algae, which reduces catch efficiency. The intensity of algae growth depends on water temperature (Zaucha and Matulaniec 1997). During the summer, this gear has to be taken down every one to two weeks, dried, and then rinsed under high pressure. The labour intensity, this operation requires, and the low efficiency of the catches and poor economic results means that during the period of high water temperatures the fishing effort is smaller.

The characteristics of the Vistula Lagoon fish assemblages are linked to local and seasonal hydrochemical conditions. The western regions are under the influence of the river mouth and the canals of the Vistula River. This shallow region is oligohaline with a stable current direction, and a developed shoreline overgrown with submerged and emerged vegetation. The fish assemblages are dominated by cyprinid fishes (roach, common bream, Prussian carp, and tench) and Northern pike that occur rarely in other regions of the lagoon (Psuty-Lipska and Borowski 2003). Fishers from Kąty Rybackie and Suchacz deploy fyke nets in the western region. The eastern fishing ground, near the border, is the deepest in the Polish part of the lagoon, and it is also the area with the highest salinity (3-5 PSU) and highly dynamic water currents determined by the direction and strength of the wind. The fish assemblage is dominated periodically by percids (European perch, pike-perch) or cyprinids (mainly common bream). Fishers deploying fyke nets in the region near the border count on catching fish migrating from the Russian- to the Polish side (Bogumił Banach, personal communication). Data collected by Psuty-Lipska and Borowski (2003) confirm that the fishers do indeed choose the most efficient fishing grounds. In the eastern region, the mean eel fishing efficiency in the 1995-2000 period was 2.3 individuals per fyke net per day, while in the other areas it fluctuated from 0.8 to 1.2 individuals per fyke net per day.

The availability of eel stocks had the greatest impact on fishing efficiency. The Vistula Lagoon was stocked with glass eel in the 1970-1994 period, and this highly effective program permitted the intense development of fyke net fisheries (Filuk and Draganik 1980, Psuty and Draganik 2008). In 1984, the mean annual efficiency per fisher was $532 \mathrm{~kg}$ (Henryk Miłaszewski, unpublished). Fishing crews were usually comprised of two fishers that received one fishing licence in 2004 for use on fishing 


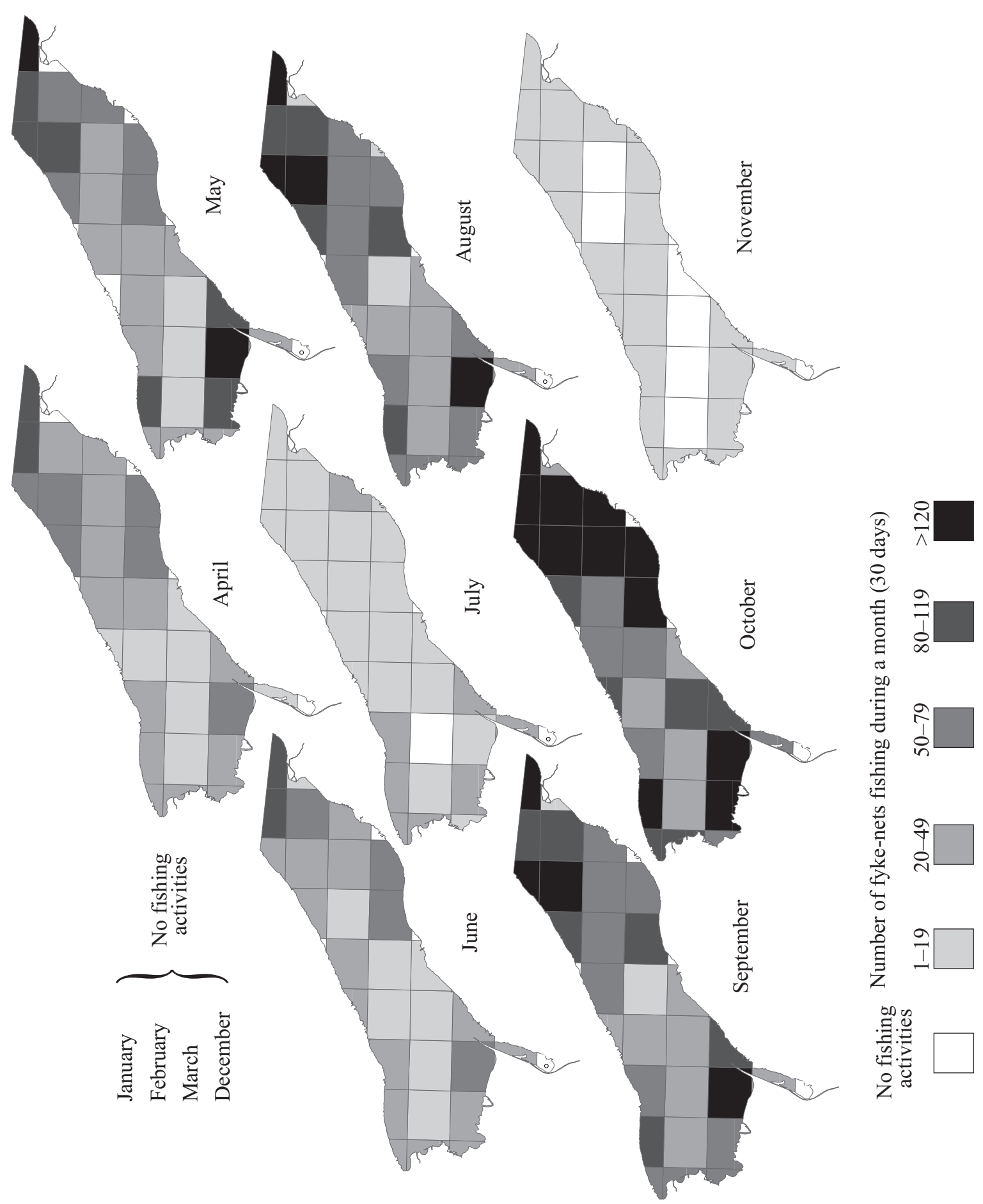

Fig. 4. Distribution of fyke nets in the lagoon in subsequent months of 2000

boats. The efficiency of the order of $1 \mathrm{t}$ per licence (crew) was stable at Katy Rybackie during the period analyzed. Although the decrease in eel efficiency was already apparent to the fishers in 2000, it was not until five years later that poor economic results prompted many fishers to resign from fishing. The fishing boat-scrapping program co-financed by the EU as part of the Common Fisheries Policy reduced by half the number of boats operating on the Polish side of the Vistula Lagoon.

The results of the current work confirm a distinct decreasing trend in efficiency, except in 2003 when the overall catches in the Vistula Lagoon were higher than in the previous and subsequent years even though the fishing effort was at the same level. The fishing bases at Piaski and Kąty Rybackie contributed the greatest share to this record result. The largest catches at both of these bases were noted in October. Similar increases were not noted in this year at any of the other fishing bases. The catch statistics made available by the co-manager of the lagoon, the Kaliningrad Oblast in Russia, do not diverge from the mean catches of that period. No extreme environmental conditions, such as high or low water temperatures in the summer, were noted in 2003, and the authors are not aware of any other anomalies on either the Polish or 
Table 3

Fishing efficiency of eel from official statistics at three fishery bases at different geographic locations

\begin{tabular}{lccc}
\hline Month & $\begin{array}{c}\text { 2000-2002 } \\
\text { (mean) }\end{array}$ & 2003 & $\begin{array}{c}\text { 2005-2007 } \\
\text { (mean) }\end{array}$ \\
\hline March & 0.2 & 0.0 & 0.1 \\
April & 2.5 & 2.1 & 5.4 \\
May & 15.1 & 14.0 & 22.8 \\
June & 6.3 & 17.3 & 17.8 \\
July & 5.4 & 6.0 & 12.5 \\
August & 12.9 & 7.5 & 12.0 \\
September & 41.3 & 23.4 & 17.9 \\
October & 15.2 & 29.0 & 9.2 \\
November & 1.0 & 0.6 & 2.1 \\
December & 0.1 & 0.1 & 0.1 \\
\hline
\end{tabular}

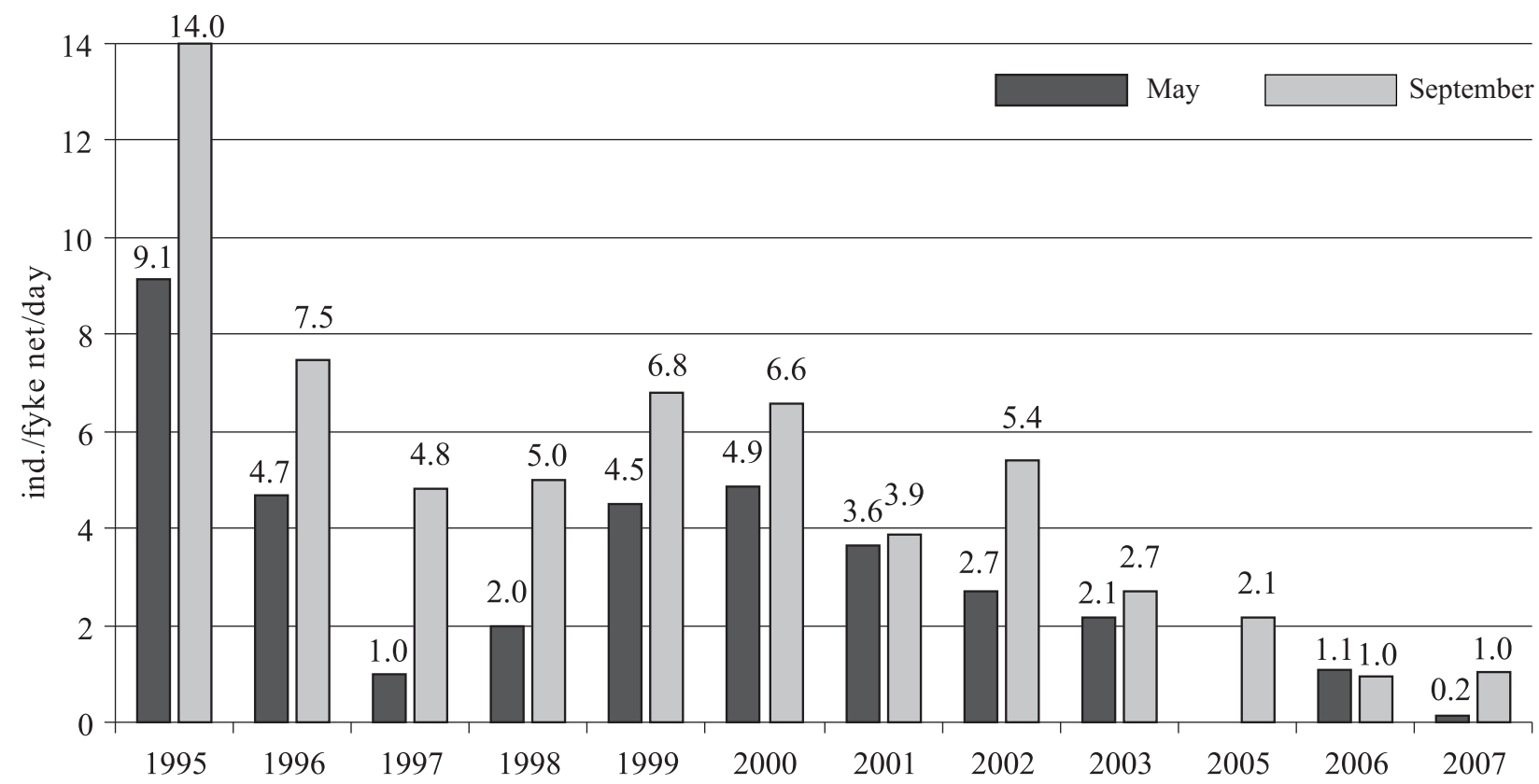

Fig. 5. Relative eel fishing efficiency in fyke net complexes in the border region in May and September

Table 4

Fishing efficiency of eel from official statistics at three fishery bases at different geographic locations

\begin{tabular}{lccc}
\hline \multirow{2}{*}{ Year } & \multicolumn{3}{c}{ Fishing efficiency of eel in kg per licence } \\
\cline { 2 - 4 } & $\begin{array}{c}\text { Kąty Rybackie } \\
\text { (southwest) }\end{array}$ & $\begin{array}{c}\text { Piaski } \\
\text { (northeast) }\end{array}$ & $\begin{array}{c}\text { Tolkmicko } \\
\text { (central) }\end{array}$ \\
\hline 2000 & 905.5 & 305.1 & 472.8 \\
2001 & 851.1 & 129.0 & 446.9 \\
2002 & 550.3 & 101.3 & 280.9 \\
2003 & 471.9 & 469.3 & 246.0 \\
2004 & 368.6 & 181.7 & 183.0 \\
2005 & 559.9 & 302.6 & 195.8 \\
2006 & 495.1 & 238.5 & 205.4 \\
2007 & 417.3 & 287.2 & 71.1 \\
\hline
\end{tabular}

Russian sides of the Vistula Lagoon or its catchment. This Vistula Spit only in October. The problem of the catch lack of knowledge, however, does not exclude the possi- statistic outlier in 2003 remains an issue for further study. bility that such an anomaly did occur and could have been Since 2003, fyke nets deployed in the Vistula Lagoon responsible for the increased eel migration near the are required to be equipped with a selective device 
(sieve), thanks to which the share of pike-perch and common bream fry caught has been reduced (Psuty-Lipska 2005). The openings in the sieve also provide an escape route for most ruffe and eel smaller than the minimum landing length $(\mathrm{MLL}=50 \mathrm{~cm}$ TL). Despite this, the share of eel in fyke net catches in 2004 did not exceed 3\% of the catch weight, and less than $1 \%$ of the total catch (Psuty-Lipska 2005). Despite the installation of the selective sieves, undersized pike-perch and bream were caught. Vistula Lagoon fishers sort fish aboard dry boats; this operation lasts at least several minutes. If the discarded fish are not already dead, they fall prey to gulls (Szymon Bzoma, personal communication). The reduction of the fyke net catch effort reduced this phenomenon, which permits the conclusion that has led to the increased survival of the smallest fish that are discarded into the water.

Unfortunately, there is a second side to the reduction in the number of fyke nets deployed. Fishers that have remained active in the Vistula Lagoon have adopted various strategies to survive the lack of eel. Those from the fishing bases located on the Vistula Spit (northern lagoon) can work in the tourist sector in the summer. Most frequently, they rent rooms, run fried-fish bars, and sell smoked fish. Fishers from the southern fishing bases have also attempted to supplement their incomes in this way; however, this region is less popular with tourists and the infrastructure is less developed. Another way is to shift the target of the fisheries to pike-perch. The gear deployed to catch this species is a gill net, and it has advantages over the fyke net, which can also be used to fish this species, as they are easier to deploy, take down, and clear of algae fouling. They are also much cheaper. Unfortunately, the lack of regulations on the construction of these gears has led to the limited selectivity of these, theoretically highly selective, gear (Psuty 1996). Additionally, the deployment of illegal gear with smaller mesh sizes $(36,40,45 \mathrm{~mm})$ is also noted increasingly. As a result, the pike-perch of the Vistula Lagoon currently exhibit characteristics of growth overfishing (Goloubkova et al. 2005). The destruction of this population can only be effectively prevented by once again increasing eel fishing efficiency from fyke nets. Thanks to the reinstatement in 2005 of the eel fry stocking program in the Vistula Lagoon, it will soon be possible to verify this hypothesis.

\section{REFERENCES}

Filuk J., Draganik B. 1980. Ocena efektywnosci zarybiania Zalewu Wiślanego węgorzem szklistym w latach 1970-1978. [The estimation of effectiveness of glass eel stocking in the years 1970-1978.] Studia i Materiały Morskiego Instytutu Rybackiego w Gdyni B 47: 5-33. [In Polish.]

Golubkova T., Draganik B., Psuty-Lipska I. 2005. Pikeperch (Sander lucioperca (L.)) abundance, exploitation, and management in the Vistula Lagoon. Bulletin of Sea Fisheries Institute 2005 (165): 3-22.

Krzymiński W., Kruk-Dowgiałlo L., Zawadzka-Kahlau E., Dubrawski R., Kamińska M., Lysiak-Pastuszak E. 2004. Typology of Polish marine waters. Coastline Reports 4: 39-48.

Lazarienko N.N., Majewski A. (eds.) 1975. The hydrometeorological system of the Vistula Lagoon. Wydawnictwo Komunikacji i Łączności, Warszawa. [In Polish.]

Psuty I. 1996. Selectivity in gill-net fishery for pikeperch in the Polish part of the Vistula Lagoon. Bulletin of Sea Fisheries Institute 1996 (139): 13-28.

Psuty-Lipska I. 2005. Retained and discarded catches from eel fyke-net fishery in the Vistula Lagoon. Bulletin of Sea Fisheries Institute 2005 (165): 51-62.

Psuty-Lipska I., Borowski W. 2003. Factors affecting fish assemblages in the Vistula Lagoon. Archive of Fishery and Marine Research 50 (3): 253-270.

Psuty I., Draganik B. 2008. The effectiveness of glass eel stocking in the Vistula Lagoon, Poland. Acta Ichthyologica et Piscatoria 38: 103-111.

Moriarty C. 1996. The decline in catches of European elver 1980-1992. Archives of Polish Fisheries 4: 245-248.

Moriarty C., Dekker W. 1997. Management of the European eel. Fisheries Bulletin 15: 1-110 pp.

Sztompka P. 1996. Looking back: The year 1989 as a cultural and civilisation break. Communists and Post-Communists Studies 29 (2): 115-130.

Wilkońska H., Psuty I. 2008. Using the side-selective fyke net barrier to research fish assemblages at the transitional and transboundary waters of the Vistula Lagoon, southern Baltic. Journal of Applied Ichthyology 24: 650-657.

Zaucha J., Matulaniec M. 1997. Anti-overgrowth finishing of fishing nets by using biocides of low toxicity to the aquatic environment. Bulletin of Sea Fisheries Institute 1997: 77-96.

Received: 10 April 2008

Accepted: 5 September 2008

Published electronically: 30 November 2008 